\title{
Evaluation of surface plasmon field-enhanced fluorescence spectroscopy for rapid measurement of progesterone concentration in bitches
}

\author{
Alain Fontbonne $\mathrm{PhD}, \mathrm{MSc}$, DVM \\ Cindy Maenhoudt DVM \\ Sandra Thoumire MSC \\ Juliette Roos DVM \\ Zuzanna Niewiadomska DVM \\ Guillaume Robiteau DVM \\ Edwige Rousselière MS \\ Thierry Buronfosse $\mathrm{PhD}, \mathrm{MS}_{\mathrm{c}}, \mathrm{DVM}$
}

Received June 24, 2020.

Accepted September 22, 2020.

From the Unité de Médecine de l'Elevage et du Sport (Fontbonne, Maenhoudt, Roos, Niewiadomska, Robiteau) and Centre d'Etude en Reproduction des Carnivores (Fontbonne, Maenhoudt, Thoumire, Roos, Niewiadomska, Robiteau), Ecole Nationale Vétérinaire d'Alfort, 94700 Maisons-Alfort, France; and Service de Biochimie, VetAgro Sup, 69280 Marcy l'Etoile, France (Rousselière, Buronfosse).

Address correspondence to Dr. Fontbonne (alain. fontbonne@vet-alfort.fr).

\begin{abstract}
OBJECTIVE
To compare progesterone (P4) concentrations measured with surface plasmon field-enhanced fluorescence spectroscopy (SPFS) and chemiluminescence immunoassay (CLIA) in serum and plasma samples of client-owned bitches of various ages and breeds and to determine reference ranges for $\mathrm{P} 4$ concentrations at various stages of the estrous cycle.
\end{abstract}

SAMPLES

102 serum samples and 104 plasma samples.

\section{PROCEDURES}

In experiment I, I aliquot each of serum and plasma was analyzed for P4 concentration by use of SPFS incorporated in a veterinary-specific pointof-care immunologic analyzer and CLIA. In experiment 2 , serum collected from bitches in various stages of the estrous cycle was analyzed for P4 concentration by use of SPFS to establish reference ranges for each stage.

\section{RESULTS}

In experiment I, P4 concentrations measured by SPFS and CLIA were highly correlated (serum, $r=0.966$; plasma, $r=0.968$ ). In experiment 2 , ranges of serum basal (proestrous) P4 concentrations $(n=114)$ and P4 concentrations at the estimated time of ovulation (76), during pregnancy or diestrus (107), and during the prepartum period (50) measured with SPFS were 0.42 to $1.46 \mathrm{ng} / \mathrm{mL}$, 3.69 to $7.85 \mathrm{ng} / \mathrm{mL}$, 11.73 to $28.24 \mathrm{ng} / \mathrm{mL}$, and 1.54 to $3.22 \mathrm{ng} / \mathrm{mL}$, respectively.

\section{CONCLUSIONS AND CLINICAL RELEVANCE}

Because serum and plasma P4 concentrations measured with SPFS were highly correlated with those measured with CLIA and ranges of serum P4 concentrations measured with SPFS for each of phase of the estrous cycle were well-defined for the large sample size, veterinarians may be able to accurately use this veterinary-specific point-of-care immunologic analyzer with SPFS methodology to determine $\mathrm{P} 4$ concentrations of bitches in their daily practice. (Am J Vet Res 202I;82:417-424)
$\mathrm{P}_{\mathrm{n}}^{\mathrm{l}}$ lasma and serum $\mathrm{P} 4$ concentrations aid in determining the optimal breeding time in bitches. Ovulation in the bitch occurs about 36 to 50 hours after attainment of peak LH concentration. ${ }^{1}$ Prior to that, serum $\mathrm{P} 4$ concentration is $<1 \mathrm{ng} / \mathrm{mL}$ and then increases before ovulation, such that the day of the preovulatory peak LH concentration can be estimated by evaluating $\mathrm{P} 4$ concentrations. ${ }^{2}$ Mean \pm SD $\mathrm{P} 4$ concentrations on the day of peak LH concentration are reported as $2.95 \pm 1.2 \mathrm{ng} / \mathrm{mL}$ (plasma), ${ }^{3} 2.56 \pm 0.30$ $\mathrm{ng} / \mathrm{mL}$ (plasma), ${ }^{4}$ and $2.02 \pm 0.18 \mathrm{ng} / \mathrm{mL}$ (serum). ${ }^{5} \mathrm{De}$ Gier et $\mathrm{al}^{6}$ found that the rapid rise of $\mathrm{P} 4$ concentration around the time of ovulation may be a more reliable marker of ovulation than the preovulatory peak LH

$\begin{array}{ll}\text { ABBREVIATIONS } \\ \text { CLIA } & \text { Chemiluminescence immunoassay } \\ \text { ELFA } & \text { Enzyme-linked fluorescent assay } \\ \text { LH } & \text { Luteinizing hormone } \\ \text { P4 } & \text { Progesterone } \\ \text { RIA } & \text { Radioimmunoassay } \\ \text { SPFS } & \begin{array}{l}\text { Surface plasmon field-enhanced fluorescence } \\ \text { spectroscopy }\end{array}\end{array}$

concentration. Plasma $\mathrm{P} 4$ concentrations on the day of ovulation are reported as $\pm 11 \mathrm{ng} / \mathrm{mL}^{7} 4$ to $10 \mathrm{ng}$ / $\mathrm{mL},{ }^{8} 2.5 \pm 0.3 \mathrm{ng} / \mathrm{mL}($ mean $\pm \mathrm{SD}),{ }^{9} 4.9 \pm 1.0 \mathrm{ng} / \mathrm{mL},{ }^{10}$ $5.44 \pm 0.93 \mathrm{ng} / \mathrm{mL},{ }^{4} 7.2 \pm 1.7 \mathrm{ng} / \mathrm{mL},{ }^{11} 5.39 \pm 1.52 \mathrm{ng} /$ $\mathrm{mL},{ }^{a}$ and $6.42 \pm 1.53 \mathrm{ng} / \mathrm{mL}$. ${ }^{\mathrm{a}}$ Progesterone concentrations are also measured when assessing normal luteal function during pregnancy and confirming luteolysis before parturition, ${ }^{12}$ often aiding in the decision of whether to perform a caesarean section such that the risk of delivering premature neonates is low.

Radioimmunoassay is often considered as the gold-standard method for measuring P4 concentrations because it is highly sensitive, specific, and repeatable. ${ }^{13}$ However, RIA requires specialized laboratory equipment (eg, gamma counter) and radioactive molecules. Most veterinary diagnostic laboratories use a CLIA. ${ }^{\mathrm{b}-\mathrm{d}}$ In veterinary hospitals, ELISAs can be used to measure P4 concentrations, and ELISA results have been compared with RIA ${ }^{14}$ and CLIA $^{15}$ results. Surface plasmon field-enhanced fluorescence spectroscopye is a new methodology available for in-hospital measurement of $\mathrm{P} 4$ concentrations. ${ }^{16}$ 
This assay does not require washing of surplus fluorescent beads, thereby enabling the realization of a compact immunodiagnostic analyzer with quantitative results in approximately 10 minutes and enabling veterinarians to use $\mathrm{P} 4$ concentrations for rapid patientside management. The objectives of the study reported here were to compare serum and plasma $\mathrm{P} 4$ concentrations measured by use of SPFS incorporated in a veterinary-specific point-of-care immunologic analyzer and with CLIA and to establish reference ranges for $\mathrm{P} 4$ concentrations measured with SPFS at baseline (ie, basal concentration), at the time of estimated ovulation, at various times during pregnancy or diestrus, and during the prepartum period.

\section{Materials and Methods}

\section{Animals}

The study protocol was approved by the institutional clinical ethical committee. Owners of enrolled dogs gave written consent to participate. Blood samples were obtained from bitches of various ages and breeds and in various stages of the estrous cycle that were presented to the hospital for routine examination that necessitated measurement of $\mathrm{P} 4$ concentration. Owners were asked to not feed their dogs on the morning of blood collection, and dogs were not sedated for blood collection.

\section{Experiment I}

The objective for experiment 1 was to determine the level of agreement between SPFS ${ }^{\mathrm{e}}$ and CLIA. ${ }^{\mathrm{c}}$ The total volume of blood collected varied between $8 \mathrm{~mL}$ (small dogs) and $10 \mathrm{~mL}$ (large dogs); each sample was transferred to a dry blood collection tube (without serum separator gel or anticoagulant) and a blood collection tube containing heparin. ${ }^{\mathrm{f}}$ To prepare the serum, the blood-filled dry blood collection tube was stored at room temperature $\left(25^{\circ} \mathrm{C}\right)$ for approximately $30 \mathrm{~min}$ utes to permit clot formation. Then, the tube was centrifuged $\left(2,500 \times g\right.$ at $25^{\circ} \mathrm{C}$ for 15 minutes), the serum was retrieved, and 2 aliquots were prepared. The plasma was prepared within 30 minutes of blood sample collection. The heparinized blood collection tube was carefully mixed by an oscillator before centrifugation $\left(2,500 \times g\right.$ at $25^{\circ} \mathrm{C}$ for 15 minutes). Then, the plasma was retrieved, and 2 aliquots were prepared. Therefore, a total of 4 aliquots ( 2 each of serum and plasma) were prepared. One aliquot each of serum and plasma was immediately assayed for $\mathrm{P} 4$ concentration with SPFS, according to the manufacturer's directions. ${ }^{e}$ The other aliquots ( 1 each) of serum and plasma were stored at $-20^{\circ} \mathrm{C}$ for up to 3 months until analysis with a CLIA at an external laboratory. ${ }^{g}$ Aliquots were shipped frozen on dry ice to the laboratory within 24 hours after packing. Progesterone concentrations measured with SPFS were not disclosed to personnel at the laboratory. Upon arrival at the laboratory, samples were thawed at $20^{\circ} \mathrm{C}$ for 10 minutes and then centrifuged ( $4,000 \times g$ at $4^{\circ} \mathrm{C}$ for 10 minutes). Laboratory person- nel performed quality control procedures daily for the CLIA with plasma and serum samples that had low (mean $\pm \mathrm{SD}, 0.88 \pm 0.15 \mathrm{ng} / \mathrm{mL})$, moderate $(8.5 \pm 1.22$ $\mathrm{ng} / \mathrm{mL})$, and high $(20.1 \pm 2.81 \mathrm{ng} / \mathrm{mL}) \mathrm{P} 4$ concentrations. According to the manufacturer ${ }^{c}$ of the CLIA, intra-assay and interassay variation is $7.0 \%$ to $17.4 \%$ and $9.5 \%$ to $20.7 \%$, respectively, with variation dependent on the $\mathrm{P} 4$ concentration.

\section{Experiment 2}

The objective of experiment 2 was to establish ranges for serum $\mathrm{P} 4$ concentrations measured with SPFS at baseline, at the estimated time of ovulation, at various times during pregnancy (or during diestrus), and during the prepartum period. Blood samples were collected and aliquots of serum were prepared as described for experiment 1 , with the exception that 3 (vs 2) aliquots were prepared. One aliquot was immediately assayed for P4 concentration with SPFS, and 1 aliquot was immediately assayed for $\mathrm{P} 4$ concentration with an ELFA, ${ }^{\mathrm{h}}$ the routine method used at the hospital for measuring $\mathrm{P} 4$ concentrations. The last aliquot was stored at $-20^{\circ} \mathrm{C}$ for up to 3 months until analysis with a CLIA at the same laboratory ${ }^{g}$ as for samples in experiment 1.

Serum P4 concentrations were considered as basal concentrations during the first 6 days of proestrus, which was confirmed with vaginal cytology (with review of the entire slide, $>60 \%$ of the vaginal mucosal cells were round and nucleated cells [intermediate and parabasal cells]). ${ }^{17}$ Ovulation was defined as the time when $\mathrm{P} 4$ concentrations were $>10$ $\mathrm{ng} / \mathrm{mL}$ on the basis of an ELFA, ${ }^{15}$, h vaginal cytology revealed $>70 \%$ superficial cells, and follicular collapse or shrinkage was observed ultrasonographically. a To assess whether serum $\mathrm{P} 4$ concentrations near the estimated time of ovulation differed among bitches of various sizes, each $\mathrm{P} 4$ concentration was allocated on the basis of a dog's body weight to 1 of 4 groups as follows: miniature ( 0 to $10 \mathrm{~kg}$ ), medium ( $>10$ to $25 \mathrm{~kg}$ ), large (> 25 to $50 \mathrm{~kg}$ ), and giant (> $50 \mathrm{~kg}$ ). Serum $\mathrm{P} 4$ concentrations were considered to be during the time of pregnancy or diestrus on the basis of vaginal cytology ${ }^{17}$ until 1 week prior to the expected time of parturition (in pregnant bitches) or 55 to 56 days after ovulation (in nonpregnant bitches). Serum $\mathrm{P} 4$ concentrations from 50 bitches of various breeds were considered to be during the time of the prepartum period on the basis of evaluation of those dogs 61 to 62 days after ovulation ${ }^{18}$ and of delivery within the subsequent 48 hours. Progesterone concentrations were determined with SPFS for other bitches (Beagles) that delivered naturally $(n=24)$ or underwent an elective caesarean section (8; mostly brachycephalic or giant breed dogs). ${ }^{19}$

\section{Statistical analysis}

The data were analyzed with 2 commercially available software programs ${ }^{\mathrm{i}, \mathrm{j}}$ and compared by use of 2 regression models: Deming regression and Passing-Bablok 
regression. The first considers measurement errors for compared methods; the second does not require special assumptions about sample allocation and measurement errors. A Bland-Altman plot was also constructed to evaluate the agreement between 2 quantitative measurements. ${ }^{20}$ Both SPFS and CLIA had the same P4 limits of quantification $(0.20$ to $40 \mathrm{ng} / \mathrm{mL})$. Values below the lower or above the upper limit of quantification were rejected for regression analyses. In experiment 2, P4 concentrations near the estimated time of ovulation between bitches of various sizes were analyzed by use of the Student $t$ test after confirmation that the distribution did not exclude the possibility of a normal distribution (null hypothesis reject) with the D'Agostino K-squared test and the Kolmogorov-Smirnov test.

\section{Results}

\section{Experiment I}

Serum $(n=102)$ and plasma (104) P4 concentrations were measured with SPFS and CLIA. For these samples, the lowest and highest $\mathrm{P} 4$ concentrations

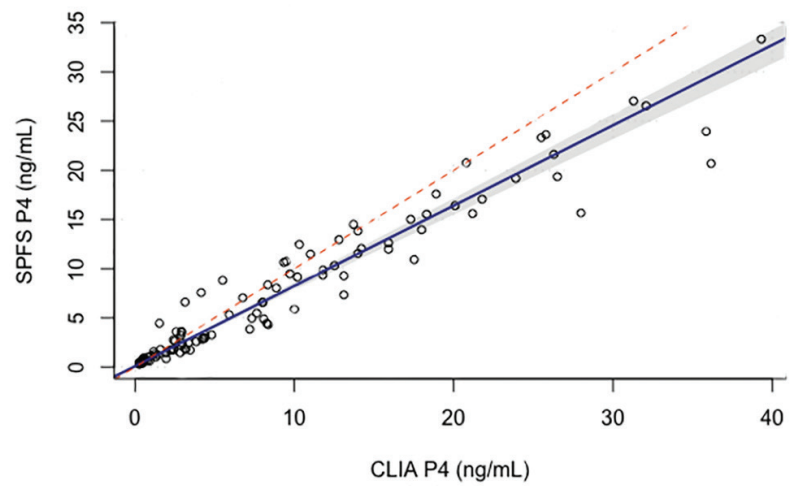

Figure I-Passing-Bablok regression plot of serum P4 concentrations $(n=102)$ determined with SPFSe and CLIAc for samples obtained from bitches presented for routine examination and measurement of P4 concentration. The solid line represents the regression line, with the gray shading representing its $95 \% \mathrm{Cl}$. The dotted line represents the identity line (slope $=I$ and $y$-intercept $=0)$. Regression line: $y=0.82 x$ $+0.08 ; r=0.966$.

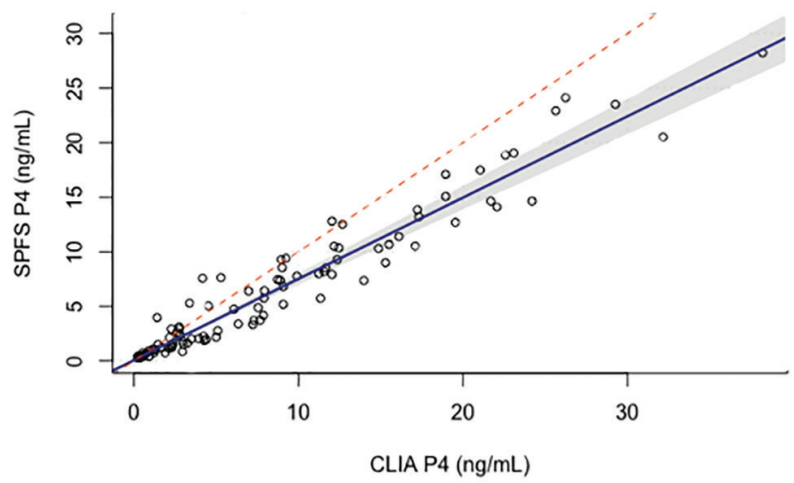

Figure 2-Passing-Bablok regression plot of plasma P4 concentrations $(n=104)$ determined with SPFS and CLIA. Regression line: $y=0.77 x+0.03(r=0.968)$. See Figure I for key. were within each analyzer's limit of quantification. The range of serum $\mathrm{P} 4$ concentrations measured with SPFS was 0.29 to $33.33 \mathrm{ng} / \mathrm{mL}$ and with CLIA was 0.25 to $39.31 \mathrm{ng} / \mathrm{mL}$. The range of plasma $\mathrm{P} 4$ concentrations measured with SPFS was 0.26 to $29.23 \mathrm{ng} / \mathrm{mL}$ and with CLIA was 0.22 to $37.74 \mathrm{ng} /$ $\mathrm{mL}$. Correlation between the results of the assays was high (serum, $r=0.966$; plasma, $r=0.968$; Figures I and 2).

By analyzing the Bland-Altman plot, mean (range) biases between the 2 assays were $1.57 \mathrm{ng} / \mathrm{mL}$ (3.20 to $6.35 \mathrm{ng} / \mathrm{mL}$ ) for serum $\mathrm{P} 4$ concentration and $1.80 \mathrm{ng} /$ $\mathrm{mL}$ ( 2.18 to $7.43 \mathrm{ng} / \mathrm{mL}$ ) for plasma $\mathrm{P} 4$ concentration (Figures 3 and 4). A proportional bias tendency was observed for both serum $(r=0.67)$ and plasma $(r=$ 0.66). The Passing-Bablok regression analyses yielded a slope of $0.82 \mathrm{ng} / \mathrm{mL}$ (95\% CI, 0.77 to $0.85 \mathrm{ng} / \mathrm{mL}$; $P<0.001)$ and an intercept of $0.09 \mathrm{ng} / \mathrm{mL}(95 \% \mathrm{CI}$, -0.09 to $0.25 \mathrm{ng} / \mathrm{mL}$ ) for serum samples and a slope

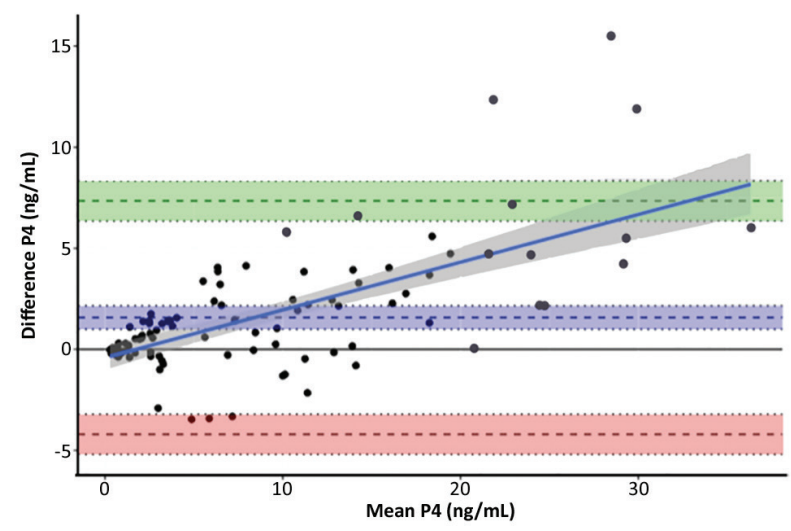

Figure 3-Bland-Altman plot of agreement between 102 pairs of serum P4 concentrations determined with SPFS and CLIA.c The dashed blue line represents the mean difference (bias) between P4 concentrations determined with each assay, and the blue shading represents the $95 \% \mathrm{Cl}$ of that difference. The dashed pink and green lines (and shading) represent the mean \pm 2 SD $(95 \%$ level of agreement) and $95 \%$ Cls. The solid blue line is the regression line of the differences $(r=$ $0.67)$. The black line indicates 0 bias.

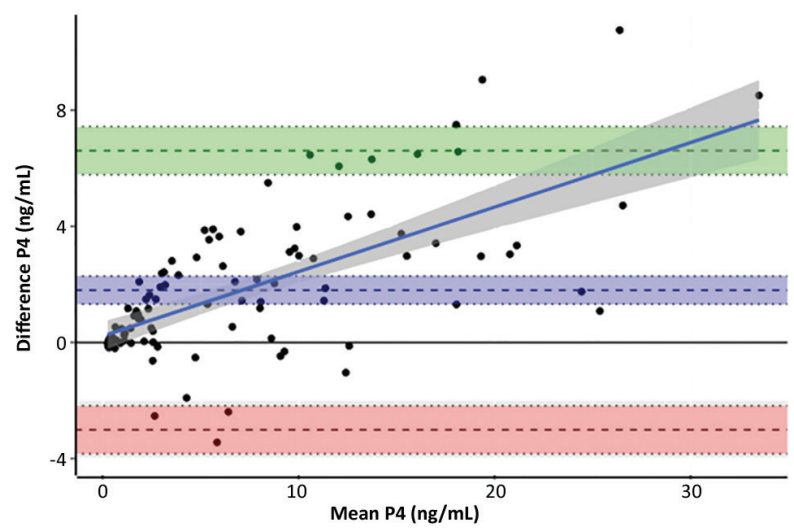

Figure 4-Bland-Altman plot of agreement between 104 pairs of plasma P4 concentrations determined with SPFS and CLIA (regression line of the differences, $r=0.66$ ). See Figure 3 for key. 
of $0.77 \mathrm{ng} / \mathrm{mL}(0.71$ to $0.83 \mathrm{ng} / \mathrm{mL} ; P<0.001)$ and an intercept of $0.031 \mathrm{ng} / \mathrm{mL}(0.09$ to $0.11 \mathrm{ng} / \mathrm{mL})$ for plasma samples. The Passing-Bablok regression showed comparable results but with the inclusion of a proportional bias in the interassay validation (ie, 95\% CI did not include the value of 1 for the slope but included the value of 0 for the $y$-intercept). The Deming regression analysis showed similar results with a slope of $0.79 \mathrm{ng} / \mathrm{mL}(0.74$ to $0.83 \mathrm{ng} / \mathrm{mL})$ and a y-intercept of $0.40 \mathrm{ng} / \mathrm{mL}(0.15$ to $0.95 \mathrm{ng} / \mathrm{mL})$ for serum samples and a slope of $0.80 \mathrm{ng} / \mathrm{mL}(0.76$ to $0.84 \mathrm{ng} / \mathrm{mL} ; P<$ $0.001)$ and a $y$-intercept of $0.17 \mathrm{ng} / \mathrm{mL}(-0.64$ to 0.29 $\mathrm{ng} / \mathrm{mL}$ ) for plasma samples. None of the $95 \%$ CIs for the slopes included the value of 1 .

Agreement between the 2 assays improved when the regression analysis was restricted to concentrations $<10 \mathrm{ng} / \mathrm{mL}$. With this restriction, the PassingBablok regression analyses yielded a slope of $0.89 \mathrm{ng} /$ $\mathrm{mL}(95 \% \mathrm{CI}, 0.79$ to $1.01 \mathrm{ng} / \mathrm{mL} ; P<0.001)$ and a $\mathrm{y}$ intercept of $0.06 \mathrm{ng} / \mathrm{mL}(95 \% \mathrm{CI},-0.18$ to $0.15 \mathrm{ng} / \mathrm{mL})$ for serum samples $(\mathrm{n}=69)$ and a slope of $0.86 \mathrm{ng} / \mathrm{mL}$ ( 0.78 to $0.93 \mathrm{ng} / \mathrm{mL} ; P<0.001)$ and an intercept of $-0.01 \mathrm{ng} / \mathrm{mL}(-0.15$ to 0.09$)$ for plasma samples $(72$; Figures 5 and $\mathbf{6})$.

The influence of sample type (serum vs plasma) on $\mathrm{P} 4$ concentrations measured with each assay was determined. Plasma $\mathrm{P} 4$ concentrations measured with SPFS (95\% CI, 4.75 to $7.16 \mathrm{ng} / \mathrm{mL}$ ) were decreased by a mean of $16.4 \%$, compared with serum P4 concentrations ( 5.74 to $8.51 \mathrm{ng} / \mathrm{mL}$ ). Plasma $\mathrm{P} 4$ concentrations measured with CLIA were decreased by a mean of $10.8 \%$ (6.61 to $9.82 \mathrm{ng} / \mathrm{mL}$ ) versus serum concentration $(7.35$ to $11.08 \mathrm{ng} / \mathrm{mL})$. Because of these results, only serum samples were included in experiment 2.

\section{Experiment 2}

Mean, 95\% CI, and range of $\mathrm{P} 4$ concentrations determined by SPFS and CLIA for bitches at the beginning of proestrus, at the estimated time of ovulation, during pregnancy or diestrus, and during the prepartum period were summarized (Table I). On the basis of body weight near the estimated time of ovulation, 4 dogs were categorized as miniature, 32 as medium, 25 as large, and 15 as giant, and mean \pm SD P4 concentrations at that time were $6.04 \pm 2.12 \mathrm{ng} / \mathrm{mL}, 6.05 \pm 2.37 \mathrm{ng} / \mathrm{mL}$, $5.76 \pm 1.74 \mathrm{ng} / \mathrm{mL}$, and $5.04 \pm 2.17 \mathrm{ng} / \mathrm{mL}$, respectively. Differences among groups were not significant.

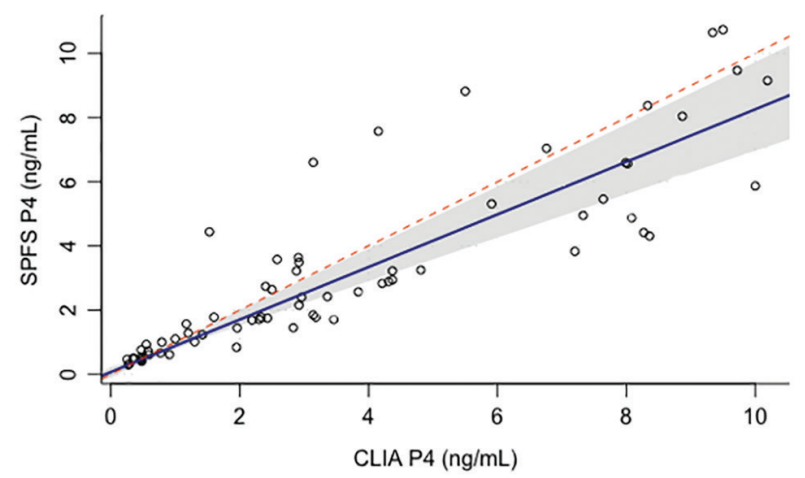

Figure 5-Passing-Bablok regression plot of serum P4 concentrations of 0 to $10 \mathrm{ng} / \mathrm{mL}(\mathrm{n}=69)$ determined with SPFS and CLIA. Regression line: $y=0.89 x+0.06(r=0.912)$. See Figure I for key.

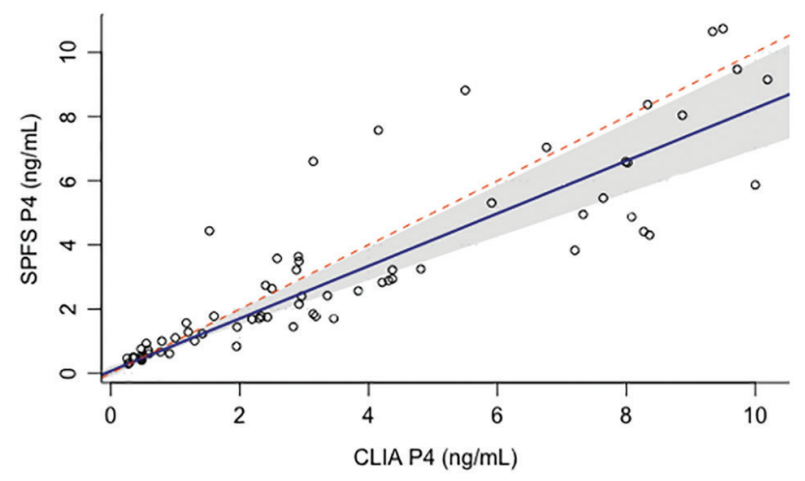

Figure 6-Passing-Bablok regression plot of plasma P4 concentrations of 0 to $10 \mathrm{ng} / \mathrm{mL}$ determined with SPFS and CLIA. Regression line: $y=0.86 x-0.0 I(r=0.93)$. See Figure I for key.

Table I-Serum progesterone concentrations during various stages of reproduction determined with SPFS and CLIA ${ }^{c}$ for bitches presented for routine examination that necessitated measurement of $\mathrm{P} 4$ concentration.

P4 concentration (ng/mL)

\begin{tabular}{lcc}
\cline { 2 - 3 } Reproductive stage & SPFS & CLIA \\
\hline Basal (proestrus; $n=114)$ & $0.78(0.70-0.88 ; 0.42-1.46)$ & $0.62(0.56-0.68 ; 0.37-1.03)$ \\
Estimated time of ovulation & $5.38(4.94-5.86 ; 3.69-7.85)$ & $6.07(5.71-6.45 ; 4.65-7.92)$ \\
$(\mathrm{n}=76)$ & $19.98(18.42-21.55 ; 11.73-28.24)$ & $20.15(18.53-21.77 ; 11.75-28.55)$ \\
Pregnancy or diestrus $(\mathrm{n}=107)$ & $2.23(2.01-2.47 ; 1.54-3.22)$ & $2.20(1.96-2.48 ; 1.44-3.36)$ \\
Prepartum period $(\mathrm{n}=50)$ &
\end{tabular}

Data are given as mean $(95 \% \mathrm{Cl}$; range). Basal stage (first 6 days of proestrus) was confirmed with vaginal cytology, estimated time of ovulation was defined as the time when P4 concentrations determined with ELFA ${ }^{\mathrm{h}}$ were $>10 \mathrm{ng} / \mathrm{mL}$ and confirmed with vaginal cytology and ultrasonography, pregnancy or diestrus was determined on the basis of vaginal cytology until I week prior to the expected time of parturition (pregnant bitches) or 55 to 56 days after ovulation (nonpregnant bitches), and prepartum period was determined on the basis of evaluation 61 to 62 days after ovulation and delivery of pups within the subsequent 48 hours. 
Mean \pm SD serum P4 concentrations measured with SPFS for prepartum bitches that the same day delivered naturally $(n=24)$ or underwent an elective caesarean section ( 8 ; mostly brachycephalic or giant breed dogs) ${ }^{19,21}$ were $1.31 \pm 0.94 \mathrm{ng} / \mathrm{mL}$ and $2.12 \pm 1.00$ $\mathrm{ng} / \mathrm{mL}$, respectively. The bitches that underwent caesarean section had a total of 51 puppies, and no puppy had signs of prematurity, such as respiratory distress, little or no hair, or difficulty suckling their mothers. Two of the 51 puppies died; one puppy was stillborn and another puppy was euthanized because of severe congenital abnormalities.

\section{Discussion}

In dogs, rapid knowledge of $\mathrm{P} 4$ concentrations is ideal for diagnosis and clinical decision-making. With an SPFS assay used in a veterinary-specific point-ofcare immunologic analyzer in the present study, quantitative results were available in approximately $10 \mathrm{~min}-$ utes. The purpose of the present study was to assess the reliability of this assay by comparing $\mathrm{P} 4$ concentrations measured with the SPFS assay with those measured with CLIA, the perceived gold standard. Other authors preferred using different reference standards, such as RIA ${ }^{13,14,22}$ or liquid chromatography-tandem mass spectrometry. ${ }^{23}$ However, RIA requires specialized laboratory equipment and radioactive molecules, such that performing the assay may be hazardous to laboratory personnel and the environment. Also, RIA is less available, compared with CLIA, and CLIA is replacing RIA in many diagnostic laboratories. In 1 study ${ }^{24}$ of 53 bitches, mean $\mathrm{P} 4$ concentrations determined with CLIA were significantly greater than those determined with RIA (mean difference, $0.69 \mathrm{ng} / \mathrm{mL}$ ). Yet, on the basis of a Pearson correlation coefficient of 0.98 , a measure of precision bias, the authors concluded that CLIA is precise and has a very good correlation with RIA. Furthermore, Gloria et $\mathrm{al}^{25}$ found that correlation $(r=0.978)$ and agreement (Lin concordance correlation coefficient, 0.966) are strong between concentrations measured with CLIA and RIA. However, results measured with different CLIA instruments ${ }^{\mathrm{b}, \mathrm{c}}$ may be possible and, therefore, affect comparisons with RIA. ${ }^{22}$ Liquid chromatography-tandem mass spectrometry, which is also considered as a reference standard for measurement of P4 concentration, was not chosen as a reference standard in the present study because of its unavailability and its limited use in veterinary medicine. ${ }^{23}$

Results of the present study with a large number of blood samples indicated that SPFS was a reliable assay for determining $\mathrm{P} 4$ concentrations over the range of concentrations for the enrolled bitches. Both SPFS and CLIA include a competitive immunoassay, but they have different detection methods. Another important difference is the calibration process associated with each assay. The SPFS instrument calibrates automatically on the basis of the QR code associated with a reagent cartridge. For CLIA, calibration is performed after failed quality control, a change of lots of reagents, and maintenance of the instrument. Internal quality controls were performed daily by use of 3 ranges of $\mathrm{P} 4$ concentrations.

Both serum and plasma samples were analyzed in the present study because both sample types are likely to be used in clinical practice. After considering the impact of preanalytical sample processing, heparinized plasma had lower $\mathrm{P} 4$ concentrations, irrespective of the assay. This difference has been reported for other species ${ }^{26,27}$ and previously described for dogs. ${ }^{28}$ Yet, the difference noted in the previous ${ }^{28}$ and present studies of dogs was not reported in another study, ${ }^{29}$ but blood collection tubes varied and the CLIA instrument ${ }^{\mathrm{b}, \mathrm{c}}$ differed. In the present study, serum samples were prepared from blood collection tubes without serum separator gel and anticoagulant and plasma samples from heparinized blood collection tubes. Differences in blood collection tubes may have contributed to the difference between serum and plasma $\mathrm{P} 4$ concentrations. Blood collected in heparinized blood collection tubes was centrifuged within 30 minutes after collection, the same time between collection and centrifugation for serum; therefore, time between collection and centrifugation was unlikely to be the cause of the differences in $\mathrm{P} 4$ concentrations between serum and plasma. With the observed differences in $\mathrm{P} 4$ concentrations between serum and plasma samples, veterinarians should try to consistently use the same blood collection tubes and, therefore, the same sample type for a specific patient.

Correlation between SPFS and CLIA was strong, which indicated that SPFS provided reliable P4 concentration results. Interestingly, agreement between the 2 assays improved when the regression analysis was restricted to the range of values $<10 \mathrm{ng} / \mathrm{mL}$, for which accurate determination is essential in clinical practice for ovulation (increasing $\mathrm{P} 4$ concentration) and prepartum (decreasing $\mathrm{P} 4$ concentration) detection. None of the $95 \%$ CIs of the slope associated with serum and plasma samples included the value of 1 , which indicated that a proportional difference existed between the 2 assays. The existence of this proportional bias signified that the 2 assays were not immediately stackable or commutable and indicated that reference intervals should ideally be established for each assay and instrument. This finding justified the necessity for experiment 2 , which aimed to establish practical ranges for the veterinary-specific pointof-care analyzer that used SPFS.

In experiment 2, analysis of the results for basal (proestrous) $\mathrm{P} 4$ concentrations determined with SPFS yielded a $95 \%$ CI of 0.70 to $0.88 \mathrm{ng} / \mathrm{mL}$. Therefore, veterinarians examining a bitch for estrus may rely on this methodology to not miss the time of peak LH concentration and, furthermore, not miss the detection of ovulation that occurs 36 to 50 hours after peak LH concentration. ${ }^{1}$

The range of $\mathrm{P} 4$ concentrations obtained at the estimated time of ovulation with SPFS in the present study was similar to that obtained with other meth- 
odologies in previous studies ${ }^{10-12, a}$ of bitches and compared favorably with CLIA. However, significant differences in $\mathrm{P} 4$ concentrations existed depending on the assay type, and such differences may confuse veterinarians. ${ }^{30}$ For example, when 1 plasma sample was divided into 7 aliquots and each aliquot was assayed for $\mathrm{P} 4$ concentration with different techniques in 7 independent laboratories, mean $\mathrm{P} 4$ concentrations were $4.6,3.6,6.8,7.2,3.9,9.2$, and $5.2 \mathrm{ng} / \mathrm{mL} .{ }^{30}$ Recent studies ${ }^{15,29,31}$ revealed that $\mathrm{P} 4$ concentrations at the estimated time of ovulation significantly differ depending on the assay type $\left(\right.$ CLIA $^{\mathrm{b}}$ : mean $\pm \mathrm{SD}, 3.4$ to $0.9 \mathrm{ng} / \mathrm{mL}$; range, 2.0 to $4.5 \mathrm{ng} / \mathrm{mL}^{31}$; $\mathrm{ELFA}^{\mathrm{h}}$ : range, 8 to $\left.10 \mathrm{ng} / \mathrm{mL}^{15}\right)$. However, $\mathrm{P} 4$ concentrations determined with SPFS at the estimated time of ovulation in the present study (mean, $5.38 \mathrm{ng} / \mathrm{mL} ; 95 \% \mathrm{CI}, 4.94$ to $5.86 \mathrm{ng} / \mathrm{mL}$; range, 3.69 to $7.85 \mathrm{ng} / \mathrm{mL}$ ) were similar to those obtained in other studies ${ }^{4,8,11}$ and often cited as reference concentrations (mean $\pm \mathrm{SD}, 5.44 \pm 0.93$ $\mathrm{ng} / \mathrm{mL}$; range, 4.51 to $6.37 \mathrm{ng} / \mathrm{mL}^{4}$; range, 4 to $10 \mathrm{ng} /$ $\mathrm{mL}^{8} ;$ mean $\left.\pm \mathrm{SD}, 7.2 \pm 1.7 \mathrm{ng} / \mathrm{mL}^{11}\right)$. Thus, SPFS should yield results that will likely aid in determining the estimated time of ovulation.

Possible reasons for the differences in $\mathrm{P} 4$ concentrations at the time of ovulation are reported. ${ }^{5,8,32,33}$ Kutzler et $\mathrm{al}^{5}$ report that mean $\mathrm{P} 4$ concentrations 2 days after the estimated time of peak $\mathrm{LH}$ concentration are dependent on the size of a bitch, with $4.62 \mathrm{ng} / \mathrm{mL}$ for giant breed dogs and $11.86 \mathrm{ng} /$ $\mathrm{mL}$ for small breed dogs. However, the results of the present study did not indicate significant differences among bitches of various sizes. Wright ${ }^{8}$ explains that any variability in $\mathrm{P} 4$ concentrations at ovulation may be associated with ovulation timing after peak LH concentration. Ovulation may occur as early as 24 hours after peak LH concentration in some bitches and up to 72 hours $^{8}$ or 96 hours later in others. ${ }^{32}$ Physiologic fluctuations in $\mathrm{P} 4$ concentrations during the estrous cycle is another possible explanation. One study ${ }^{33}$ of bitches revealed a difference of up to $12.7 \mathrm{nmol} / \mathrm{L}$ ( $4.0 \mathrm{ng} / \mathrm{mL}$ ) between $\mathrm{P} 4$ concentrations in the morning versus in the afternoon. Although collection of successive blood samples from each bitch at fixed hours was attempted in the present study, doing so was difficult because dogs were presented for examination at various times throughout a day and dog owners could not be compelled to bring their dogs to the hospital at a specific time of day; therefore, the effect of physiologic fluctuations on $\mathrm{P} 4$ concentrations at the estimated time of ovulation could not be mitigated.

For bitches that were in diestrus or pregnant, P4 concentrations determined with SPFS were much higher than those at the estimated time of ovulation (mean, 19.98 vs $5.38 \mathrm{ng} / \mathrm{mL}$ ). Therefore, SPFS was a reliable method to monitor the luteal phase in the bitches of the present study. Progesterone concentrations are also commonly used for detecting hypoluteodism during pregnancy. Hypoluteodism may result from primary premature ovarian luteal regression or secondary to the release of prostaglandins from the endometrium associated with preexisting myometrial activity. Davidson ${ }^{34}$ demonstrates that the early (< 40 days gestation) use of tocodynamometry detects myometrial hypercontractility before the development of luteal insufficiency and may therefore be useful in association with repeated determination of $\mathrm{P} 4$ concentrations during pregnancy in bitches at risk of preterm labor.

Progesterone concentrations are also commonly used to detect luteolysis before parturition and may aid in determining the day when a caesarean section could be performed with low risk of delivering premature neonates. ${ }^{12,21}$ Rota et al ${ }^{35}$ report mean \pm SD $\mathrm{P} 4$ concentrations determined with a CLIA of $4.32 \pm 2.52 \mathrm{ng} / \mathrm{mL}$ on the day preceding and $1.47 \pm 0.67 \mathrm{ng} / \mathrm{mL}$ on the day of natural parturition. Results of that study ${ }^{35}$ agree with those of the present study, in that the range of the $\mathrm{P} 4$ concentrations determined with SPFS in bitches that were 61 or 62 days after the estimated day of ovulation was 1.54 to $3.22 \mathrm{ng} / \mathrm{mL}$ (95\% CI, 2.01 to 2.47 $\mathrm{ng} / \mathrm{mL}$ ), and results included 8 bitches that underwent a caesarean section on day 61 or 62 (mean \pm $\mathrm{SD}, 2.12 \pm 1.00 \mathrm{ng} / \mathrm{mL}$ ). Furthermore, the 24 Beagle bitches that had naturally delivered had a mean \pm SD P4 concentration of $1.31 \pm 0.94 \mathrm{ng} / \mathrm{mL}$ on the day of delivery. In the scientific literature, ${ }^{11,20} \mathrm{com}-$ mon opinion is that a caesarean section can be safely performed when the $\mathrm{P} 4$ concentration is $<2$ $\mathrm{ng} / \mathrm{mL}$, equating to approximately 24 to 40 hours before natural parturition. Therefore, a cutoff $\mathrm{P} 4$ concentration of $2 \mathrm{ng} / \mathrm{mL}$ as determined with SPFS could be considered.

The strength of the present study was the large number of blood samples (approx 500) that were analyzed in an attempt to minimize potential biases. However, serum and plasma samples were analyzed only once with SPFS on the basis of the coefficient of variation given by the manufacturer $(3.3 \%$ at $0.94 \mathrm{ng} / \mathrm{mL}$ and $3.0 \%$ at $28.07 \mathrm{ng} / \mathrm{mL}$ ). Another potential limitation of the present study was that serum and plasma were analyzed with SPFS within 30 minutes after sample collection and were analyzed with CLIA after the samples had been stored at $-20^{\circ} \mathrm{C}$ for up to 3 months after sample collection; the latter was necessary because the samples had to be shipped to an external laboratory for analysis with CLIA. However, $\mathrm{P} 4$ is considered to be stable in stored samples, in that up to 10 freeze-thaw cycles do not significantly affect the $\mathrm{P} 4$ concentrations determined with CLIA, with a mean P4 decrease of only $1.9 \%$ per cycle. ${ }^{29}$

The results of the present study revealed that serum and plasma $\mathrm{P} 4$ concentrations in bitches of various breeds determined with SPFS were highly correlated with those determined by use of CLIA and ranges of P4 concentrations measured with SPFS for each of the evaluated phases of the estrous cycle-low concentrations during proestrus and the prepartum period, moderate concentrations near the estimated time 
of ovulation, and high concentrations during pregnancy-were well-defined for the large sample size. Therefore, veterinarians may be able to accurately use this veterinary-specific point-of-care analyzer with SPFS methodology to determine P4 concentrations of bitches in their daily practice, including as an aid in determining the timing for a caesarean section to decrease the risk of premature delivery of neonates.

\section{Acknowledgments}

Funded by Fujifilm Corp.

The authors declare that there were no conflicts of interest.

The authors thank Dr. Karine Reynaud for her support and Felicity Leith-Ross for help with improving the best use of the English language during manuscript preparation.

\section{Footnotes}

a. Fontbonne A. In vivo ovulation, oocyte maturation and fertilsation in the bitch. PhD thesis, Institut des Sciences et Industries du Vivant et de l'Environnement, AgroParisTech, Paris, France, 2008.

b. Immulite 1000, Siemens AG, Munich, Germany.

c. Immulite $2000 \mathrm{XPi}$, Siemens AG, Munich, Germany.

d. Elecsys 2010, Roche Diagnostics, Meylan, France.

e. FUJI DRI-CHEM IMMUNO AU10V, Fujifilm Corp, Tokyo, Japan

f. Becton Dickinson, Wokingham, England

g. Service de Biochimie, VetAgro Sup, Marcy l'Etoile, France.

h. BioMérieux, Marcy l'Etoile, France.

i. GraphPad, Software, Prism 7, San Diego, Calif.

j. $\quad$ RStudio, version 1.2.1335, Boston, Mass.

\section{References}

1. Concannon PW. Canine physiology of reproduction. In: Burk TJ, ed. Small animal reproduction and infertility. Philadelphia: Lea \& Febiger, 1986;23-77.

2. England G, Concannon PW. Determination of the optimal breeding timein thebitch:basicconsiderations. In:Concannon PW, England G, Verstegen J III, et al, eds. Recent advances in small animal reproduction. Ithaca, NY: International Veterinary Service, 2002

3. Guérin C, Maurel MC, Launais M, et al. Use of an immunoenzymatic assay to detect the luteinizing hormone peak in bitches. J Reprod Fertil Suppl 1997;51:277-281.

4. Concannon P, Hansel W, Mcentee K. Changes in LH, progesterone and sexual behavior associated with preovulatory luteinization in the bitch. Biol Reprod 1977;17:604613.

5. Kutzler MA, Mohammed HO, Lamb SV, et al. Accuracy of canine parturition date prediction from the initial rise in preovulatory progesterone concentration. Theriogenology 2003;60:1187-1196.

6. de Gier J, Kooistra HS, Djajadiningrat-Laanen SC, et al. Temporal relations between plasma concentrations of luteinizing hormone, follicle-stimulating hormone, estradiol-17beta, progesterone, prolactin and alpha-melanocyte-stimulating hormone during the follicular, ovulatory, and early luteal phase in the bitch. Theriogenology 2006;65:1346-1359.

7. Arbeiter K, Dobretsberger M, Müller E, et al. Indirect detection of ovulation and fertilization in the dog by progesterone level testing [in German]. Zentralbl Veterinarmed $A$ 1991;38:696-701.

8. Wright PJ. Application of vaginal cytology and plasma progesterone determinations to the management of reproduction in the bitch. I Small Anim Pract 1990;31:335-340.

9. Jeffcoate IA, England GC. Urinary LH, plasma LH and progesterone and their clinical correlates in the periovulatory period of domestic bitches. J Reprod Fertil Suppl 1997;51:267275 .

10. Bouchard GF, Solorzano N, Concannon PW, et al. Determi- nation of ovulation time in bitches based on teasing, vaginal cytology and ELISA for progesterone. Theriogenology 1991;35:603-611.

11. Hayer P, Günzel-Apel AR, Lüerssen D, et al. Ultrasonographic monitoring of follicular development, ovulation and the early luteal phase in the bitch.J Reprod Fertil Suppl 1993;47:93100.

12. De Cramer KGM, Nöthling JO. The precision of predicting the time of onset of parturition in the bitch using the level of progesterone in plasma during the preparturient period. Theriogenology 2018;107:211-218

13. Moxon R, Copley D, England GC. Technical and financial evaluation of assays for progesterone in canine practice in the UK. Vet Rec 2010;167:528-531.

14. Brugger N, Otzdorff C, Walter B, et al. Quantitative determination of progesterone ( $\mathrm{P} 4)$ in canine blood serum using an enzyme-linked fluorescence assay. Reprod Domest Anim 2011;46:870-873.

15. Bonte $\mathrm{T}$, Rosset $\mathrm{E}$, Combe $\mathrm{P}$, et al. Performance evaluation of BioMerieux Vidas automated immunoassays for the determination of plasma progesterone in dogs, in Proceedings. 20th Eur Vet Soc Small Anim Reprod Cong 2017; 43

16. Liebermann T, Knoll W. Surface-plasmon field-enhanced fluorescence spectroscopy. Colloids Surf A Pbysico Eng Asp 200;171:115-130.

17. Schutte AP. Canine vaginal cytology II: cyclic changes. $J$ Small Anim Pract 1967;8:307-311.

18. Mir F, Billault C, Fontaine E, et al. Estimated pregnancy length from ovulation to parturition in the bitch and its influencing factors: a retrospective study in 162 pregnancies. Reprod Domest Anim 2011;46:994-998.

19. Smith FO. Challenges in small animal parturition-timing elective and emergency cesarian sections. Theriogenology 2007;68:348-353.

20. Bland JM, Altman DG. Statistical methods for assessing agreement between two methods of clinical measurement. Lancet 1986;1:307-310.

21. Roos J, Maenhoudt C, Zilberstein L, et al. Neonatal puppy survival after planned caesarean section in the bitch using aglepristone as a primer: a retrospective study on 74 cases. Reprod Domest Anim 2018;53(suppl 3):85-95.

22. Tal S, Mazaki-Tovi M, Druker S, et al. Evaluation of two chemiluminescent assays compared with radioimmunoassay for serum progesterone measurement in bitches. Theriogenology 2020;147:116-123.

23. Idexx Laboratories Inc. 2019. Catalyst progesterone for inhouse measurement of progesterone in plasma from bitches. Available at: www.idexx.com/files/catalyst-progesteronewhite-paper-en.pdf. Accessed Dec 142020.

24. Chapwanya A, Clegg T, Stanley P, et al. Comparison of the Immulite and RIA assay methods for measuring peripheral blood progesterone levels in Greyhound bitches. Theriogenology 2008;70:795-799.

25. Gloria A, Contri A, Carluccio A, et al. Blood periovulatory progesterone quantification using different techniques in the dog. Anim Reprod Sci 2018;192:179-184.

26. Owens RE, Atkins DT, Rahe $\mathrm{CH}$, et al. Time-dependent loss of radioimmunoassayable levels of progesterone following ambient temperature incubation of heparinized bovine blood. Theriogenology 1980;13:305-309.

27. Hegstad-Davies RL. A review of sample handling considerations for reproductive and thyroid hormone measurement in serum or plasma. Theriogenology 2006;66:592598.

28. Thuróczy J, Wölfling A, Tibold A, et al. Effect of anticoagulants and sampling time on results of progesterone determination in canine blood samples. Reprod Domest Anim 2003;38:386-389.

29. Tahir MZ, Thoumire S, Raffaelli M, et al. Effect of blood handling conditions on progesterone assay results obtained by chemiluminescence in the bitch. Domest Anim Endocrinol 2013;45:141-144.

30. Fraser N, Wilboen RR, Schultz W, et al. Comparative progesterone assay. Clin Theriogenology 2015;7:207-209. 
31. Schmicke M, Urhausen C, Wolf $\mathrm{K}$, et al. Evaluation of the blood progesterone concentration in the bitch measured by chemiluminescence immunoassay at the day of ovulation. Tierarztl Prax Ausg K Kleintiere Heimtiere 2016;44:317-322.

32. Wildt DE, Chakraborty PK, Panko WB, et al. Relationship of reproductive behavior, serum luteinizing hormone and time of ovulation in the bitch. Biol Reprod 1978;18:561570 .

33. Linde-Forsberg C, Ström-Holst B, Forsberg M. Daily progester- one fluctuations during the estrous cycle in the bitch, in Proceedings. 6th Int Symp Canine Feline Reprod 2008;134-135.

34. Davidson AP. Tocodynamometry detects preterm labor in the bitch before luteolysis. Top Companion Anim Med 2015;30:2-4.

35. Rota A, Charles C, Starvaggi Cucuzza A, et al. Diagnostic efficacy of a single progesterone determination to assess full-term pregnancy in the bitch. Reprod Domest Anim 2015;50:10281031 . 